\title{
Determination of Unprotonated Ammonia in Whole Cigarette Smoke*
}

\author{
by C. H. Sloan and G. P. Morie \\ Research Laboratories, Tennessee Eastman Company, Division of Eastman Kodak Company, \\ Kingsport, Tennessee, U.S.A.
}

\section{INTRODUCTION}

Several methods have been reported for the determination of ammonia in cigarette smoke $(1-7)$. Ayers (1) trapped the ammonia from cigarette smoke in $0.05 \mathrm{M}$ aqueous sulfuric acid, added base, and used a diffusion cell to isolate and concentrate the liberated ammonia. She then used gas dromatography to quantitatively determine the ammonia.

Brunnemann and Hoffmann (2) used a saturated boric acid solution to collect the ammonia from smoke. They concentrated the solution and used a gas chromatographic technique to determine the ammonia.

In 1973, the authors (5) reported the use of an ammonia electrode for the determination of ammonia in tobacco and tobacco smoke. The smoke was passed through an acidic solution to collect the ammonia, which was then isolated by steam distillation from a basic solution. An ammonia electrode was used to determine the amount of ammonia collected from the smoke.

None of the published methods distinguished between ammonium ion and free (unprotonated) ammonia. One objective of this work was to develop a method for the determination of unprotonated ammonia in cigarette smoke. The second objective was to compare the amount of experimentally measured free ammonia with the theoretical amount calculated from the total ammonia and smoke $\mathrm{pH}$. A third objective was to evaluate an improved technique for measuring the total ammonia in cigarette smoke with an ammonia electrode.

\section{EXPERIMENTAL}

\section{Calibration of Instrument}

The response of the electrode to gaseous ammonia was used as the basis for the determination of unprotonated ammonia in cigarette smoke.

The actual concentrations of gaseous ammonia to which the electrode responded were calculated from published equilibrium data (8) of aqueous ammonia solutions. Henry's Law constant was calculated from the literature data and extrapolated to infinite dilution. The extrapolated constant was then used to calculate the partial

* Received for publication: 2t st October, 1975. pressure of ammonia over known aqueous solutions of $0.1 \mathrm{ppm}, 1.0 \mathrm{ppm}$, and to $\mathrm{ppm} \mathrm{NH}_{3}$. The partial pressures were converted to concentrations by the ideal gas law. A calibration curve was prepared by plotting concentration of gaseous ammonia against electrode response.

\section{Cigarettes}

The cigarettes used in the smoking experiments consisted of a domestic nonfilter brand, two domestic filter brands, burley, bright leaf, dark tobacco, and a cigarette made from cigar-type tobacco. Two domestic little cigars were also included in the experimental work. All smoking items were conditioned for at least $4^{8}$ hours at $60 \%$ relative humidity and $75^{\circ} \mathrm{F}$ before smoking.

\section{Method}

Reagents:

a. Reagent-grade ammonium chloride, aqueous solutions were prepared with ammonia-free water to $0 . x \mathrm{ppm}$, $1.0 \mathrm{ppm}$, and $10 \mathrm{ppm} \mathrm{NH}_{3}$.

b. Sodium hydroxide, to $\mathrm{M}$ (aqueous).

c. Hydrochloric acid, o.x $\mathrm{M}$ (aqueous).

d. Saturated sodium chloride solution.

\section{Apparatus:}

a. Orion ammonia electrode Model No. 95-10 (Orion Research, Inc., 11 Blackstone St., Cambridge, Mass., 02139).

b. Orion digital Ionalyzer Model $801 \mathrm{~A}$.

c. Glass smoking chamber (Figure 1).

d. Phipps and Bird single-port syringe-type smoking machine.

e. Hewlett-Packard strip-chart recorder.

\section{Procedure}

A $1 \mathrm{ml}$ sample of saturated aqueous sodium dhloride is placed in the bottom of the smoking vessel to provide the necessary humidity for the operation of the electrode. A cigarette is then inserted in the bottom orifice provided for this purpose. The electrode is placed through the top of the chamber and extends to within 
Figure 1. Smoking chamber for determination of free ammonia.

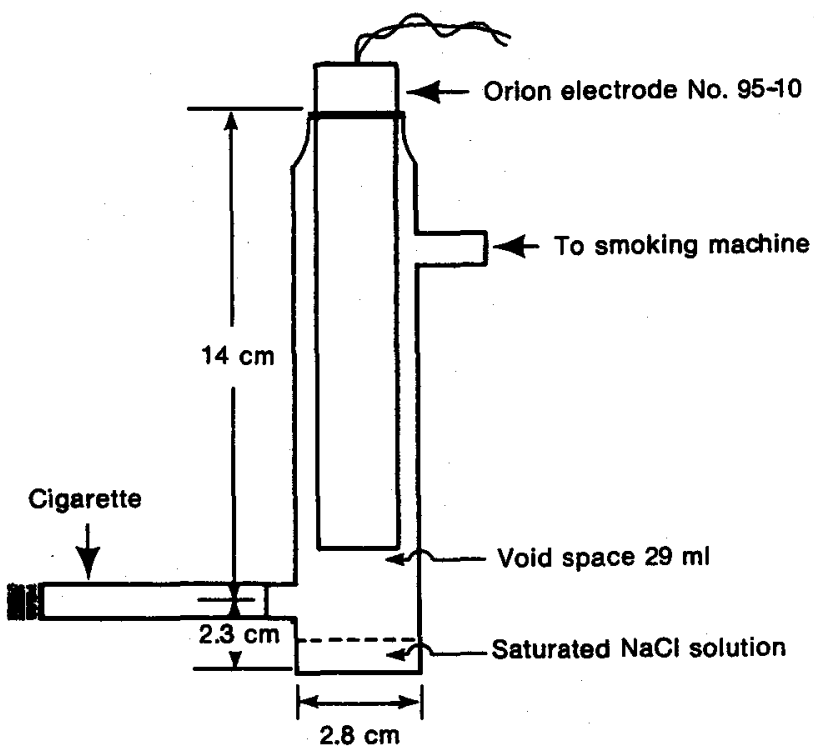

about $2.5 \mathrm{~cm}$ of the smoke inlet. The electrode is connected to the Orion digital Ionalyzer and to a stripchart recorder. The cigarette is smoked at the rate of one $35 \mathrm{ml}$ puff of $2 \mathrm{~s}$ duration once each minute. The average maximum response to each puff is used with the calibration curve to determine the concentration of free ammonia per puff. The total free ammonia per cigarette is calculated from these data.

\section{Determination of Smoke $\mathrm{pH}$}

The smoke $\mathrm{pH}$ for theoretical calculations was determined by a modification of the method described by Sensabaugh and Cundiff (9). A Markson combination electrode No. 808 was fitted with a nylon mesh sleeve; and just prior to the $\mathrm{pH}$ determination, the sleeve was moistened with a saturated sodium chloride solution. The smoking chamber designed for the ammonia analysis was used for the $\mathrm{pH}$ determination. The $\mathrm{pH}$ was recorded on a strip-chart recorder as the cigarette was smoked.

\section{Determination of Total Ammonia}

Total ammonia (protonated and unprotonated) in the cigarette smoke was determined by a modification of the ammonia electrode method of Sloan and Morie (5). The revised procedure consists of scrubbing the whole smoke from two cigarettes through $50 \mathrm{ml}$ of aqueous $0.1 \mathrm{M}$ hydrochloric acid to collect the ammonia. The scrubber contents are diluted to $100 \mathrm{ml}$ with ammoniafree water and transferred to a $125 \mathrm{ml}$ Erlenmeyer flask equipped with a rubber seal. Two milliliters of $10 \mathrm{M}$ aqueous sodium hydroxide is added to the solution, and the ammonia electrode is immediately inserted in the flask and positioned about $1 \mathrm{~cm}$ above the surface of the solution. The electrode is connected to the Orion Ionalyzer and switched to the millivolt position. The solution is stirred with a magnetic stirring bar until the meter readings are stable. The concentration of ammonia is determined from a calibration curve previously prepared from $0.1 \mathrm{ppm}, 1.0 \mathrm{ppm}$, and 1o $\mathrm{ppm}$ aqueous ammonia solutions.

\section{Response of the Electrode to Methylamine}

Total Ammonia: Methylamine was a possible source of interference in the total ammonia analysis. To determine if the amount of methylamine in cigarette smoke introduced any significant errors, the response of the electrode to the equilibrium vapors of known aqueous solutions of $0.1 \mathrm{ppm}, 1.0 \mathrm{ppm}$, and $10 \mathrm{ppm}$ methylamine was determined.

Free Ammonia: The possibility of unprotonated methylamine being an interference in the determination of free ammonia was considered. A computer program was used to calculate the species of methylamine present at the $\mathrm{pH}$ levels of $\mathrm{O}$ to 14 , to determine if any free methylamine could be present at the smoke $\mathrm{pH}$ levels of the cigarettes tested. A similar graph of ammonia (protonated and unprotonated vs. $\mathrm{pH}$ ) was superimposed on the same graph with methylamine to show the difference in the fraction of the unprotonated species of the two compounds at the $\mathrm{pH}$ of the smoke.

\section{RESULTS AND DISCUSSION}

\section{Total Ammonia in Cigarette Smoke}

All of the values obtained by the revised method for total ammonia are lower than those found by the original method (Table 1). By suspending the electrode above the solution, many of the interferences in a smoke solution, such as tars and other suspended matter, are effectively isolated from the electrode. The steam distillation cleanup of the smoke solution was no longer necessary. Elimination of this step reduced the possibility of the formation of additional ammonia through hydrolysis and reduced the analysis time by several minutes.

Slightly lower values for total ammonia were obtained in all cases with the revised method. The amount of ammonia in the smoke of the dark tobacco cigarette

Table 1. Total ammonia in clgarette smoke by the original and the revised methods (ammonla electrode).

\begin{tabular}{l|c|c|c}
\hline \multirow{2}{*}{ Cigarette } & \multicolumn{3}{|c}{ Total NH3, $\mu \mathrm{g}$} \\
\cline { 2 - 4 } & $\begin{array}{l}\text { Original } \\
\text { method }\end{array}$ & $\begin{array}{c}\text { Revised } \\
\text { method }\end{array}$ & $\begin{array}{c}\text { Change } \\
\%\end{array}$ \\
\hline Nonfilter & 58 & 44 & -24 \\
Filter 1 & 36 & 28 & -22 \\
Filter 2 & 62 & 42 & -32 \\
Bright leaf & 55 & 46 & -16 \\
Kentucky 1R1 & 64 & 59 & -8 \\
Burley & 191 & 130 & -32 \\
Dark tobacco & 152 & 147 & -3 \\
\hline
\end{tabular}


was $3.2 \%$ lower by the revised procedure. In the other cigarettes tested, the ammonia ranged from 7.8 to $32.3 \%$ lower by the revised method than was previously obtained with the original method.

\section{Unprotonated Ammonia in Cigarette Smoke}

Free (unprotonated) ammonia in the smoke of the domestic filter and nonfilter cigarettes ranged from 1 to $4 \mathrm{ng}$ (Table 2). The Kentucky $\mathrm{IRI}$ reference cigarette and the bright leaf cigarettes also were very low in free ammonia. They contained $7 \mathrm{ng}$ and $3 \mathrm{ng}$, respectively. The dark tobacco cigarette and one of the little cigars contained $1.2 \mu \mathrm{g}$ and $2.4 \mu \mathrm{g}$ of free ammonia, respectively. The burley cigarette and the other little cigar, each, contained less than $0.5 \mu \mathrm{g}$ of free ammonia.

Table 2. Experimental and calculated free ammonia in cigarette smoke.

\begin{tabular}{l|r|r|c|c}
\hline Cigarette & $\begin{array}{c}\text { Smoke } \\
\mathbf{p H}\end{array}$ & $\begin{array}{c}\text { Total } \\
\mathrm{NH}_{3}, \mu \mathrm{g}\end{array}$ & $\begin{array}{c}\text { Experimental } \\
\text { free } \\
\mathrm{NH}_{3}, \mu \mathrm{g}\end{array}$ & $\begin{array}{c}\text { Calculated } \\
\text { free } \\
\mathrm{NH}, \mu \mathrm{g}\end{array}$ \\
\hline Nonfilter & 5.36 & 44 & 0.001 & 0.005 \\
Filter 1 & 5.45 & 28 & 0.002 & 0.004 \\
Filter 2 & 5.57 & 42 & 0.004 & 0.008 \\
Bright leaf & 5.28 & 46 & 0.003 & 0.005 \\
Kentucky 1R1 & 5.17 & 59 & 0.006 & 0.004 \\
Burley & 6.41 & 130 & 0.200 & 0.200 \\
Clgar tobacco & 7.10 & 108 & 0.330 & 0.700 \\
Little cigar A & 6.85 & 98 & 0.510 & 0.810 \\
Little clgar B & 7.17 & 310 & 2.4 & 1.8 \\
Dark tobacco & 7.34 & 147 & 1.2 & 2.0 \\
\hline
\end{tabular}

The experimental values for free ammonia agreed very well with the theoretical amount calculated from total ammonia and $\mathrm{pH}$ of the smoke. In the more basic smokes such as burley, dark tobacco, and little cigars, the free ammonia increased with puff number. In Fig. 2 the recorder trace of the ammonia electrode's response

Figure 2. Recorder trace of free ammonia and pH of burley smoke.

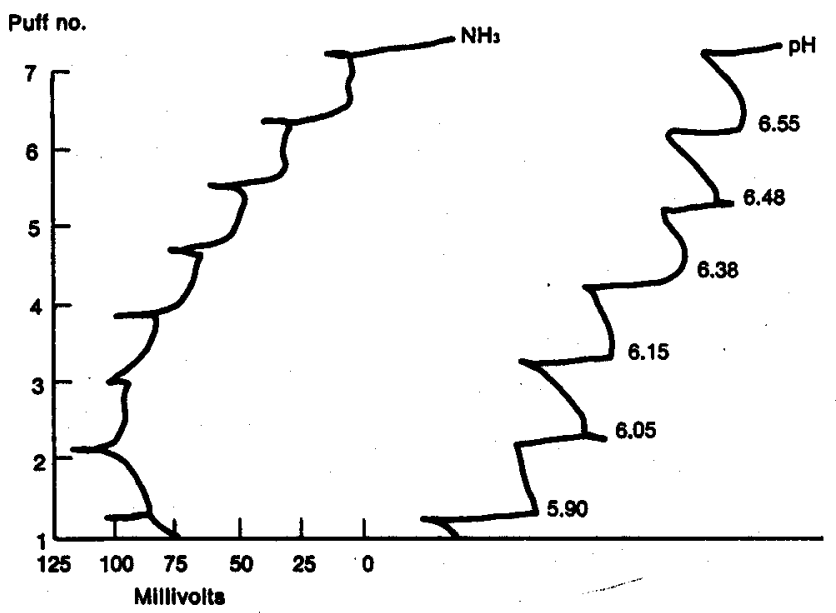

Figure 3. Fraction of tree ammonla and methylamine ve. pH.

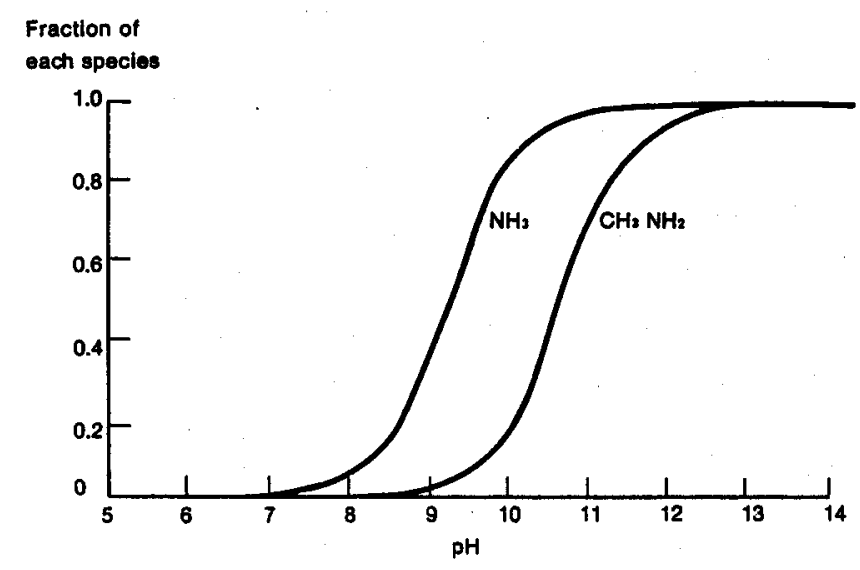

to burley smoke is shown; and in the same graph, the $\mathrm{pH}$ curve of burley smoke is shown. The increase of $\mathrm{pH}$ with puff number is consistent with the increase of free ammonia as indicated by an increasing negative response of the ammonia electrode.

\section{Response of the Ammonia Electrode to Methylamine}

The response of the ammonia electrode to the equilibrium head space vapors of aqueous methylamine solutions of $0.1 \mathrm{ppm}, 1.0 \mathrm{ppm}$, and $10 \mathrm{ppm}$ concentrations was about one tenth as great as that obtained from ammonia solutions. In addition, the methylamine concentration of cigarette smoke is about one third that of ammonia. Thus, any interference by methylamine in the determination of total ammonia was less than $3 \%$.

No unprotonated methylamine occurs in smoke having a pH less than 8. A computer-generated graph (Figure 3) showing the protonated and unprotonated ammonia and methylamine vs. $\mathrm{pH}$ indicates that while unprotonated ammonia begins to occur at $\mathrm{pH} 5.0$, no unprotonated methylamine occurs until $\mathrm{pH}$ 6.4. At this $\mathrm{pH}$ the amount of unprotonated methylamine is very small $(5 \times 10-3 \%)$ and is insignificant at the $\mathrm{pH}$ of the smoking items tested. Thus, it is presumed that no interference could have occurred from methylamine.

\section{SUMMARY}

The total ammonia content of smoke is essentially ammonium salts with insignificant amounts of free ammonia. An ammonia electrode was used to experimentally measure the amount of free ammonia in the smoke of several cigarettes and two little cigars. For comparison, the theoretical amount of free ammonia was calculated from the total ammonia content and smoke $\mathrm{pH}$. Free ammonia in domestic filter and nonfilter cigarettes ranged from 1 to $4 \mathrm{ng}$ with total ammonia contents of 28 to $44 \mu \mathrm{g}$. The smoke from a dark tobacco cigarette and little cigar contained 1.2 and $2.4 \mu \mathrm{g}$ of free $\mathrm{NH}_{3}$, respectively. These two smoking items had total ammonia contents of 147 and $310 \mu \mathrm{g}$, 
respectively. The calculated free ammonia agreed with the experimental values. No significant errors were introduced by the presence of methylamine in the smoke in either total ammonia or free ammonia results.

\section{ZUSAMMENFASSUNG}

Der Gesamtammoniakgehalt des Rauches besteht im wesentlichen aus Ammoniumsalzen und unbedeutenden Mengen freien Ammoniaks. Die Mengen freien Ammoniaks im Rauch von mehreren Cigaretten und zwei kleinen Zigarren wurden unter Verwendung einer Ammoniakelektrode experimentell gemessen. Zum Vergleich wurde die Menge freien Ammoniaks theoretisch aus dem Gesamtammoniakgehalt und dem pH-Wert des Rauches berechnet. Cigaretten des amerikanischen Marktes mit und ohne Filter enthielten 1 bis $4 \mathrm{ng}$ freies Ammoniak bei Gesamtammoniakgehalten von 28 bis $44 \mu \mathrm{g}$. Der Rauch von Cigaretten und kleinen Zigarren aus dunklem Tabak enthielt 1,2 bzw. 2,4 $\mu \mathrm{g}$ freies $\mathrm{NH}_{3}$ bei Gesamtammoniakgehalten von 147 bzw. 310 $\mu \mathrm{g}$. Die berechneten Werte für den Gehalt an freiem Ammoniak stimmten mit den experimentellen Meßergebnissen überein. Weder bei dem Gesamtammoniakgehalt noch bei freiem Ammoniak führte die Gegenwart von Methylamin im Rauch zu signifikanten Abweichungen in den Ergebnissen.

\section{RESUME}

La teneur totale de l'ammoniaque dans la fumée est essentiellement composée de sels d'ammonium et d'une partie insignifiante d'ammoniaque libre. Pour mesurer la teneur en ammoniaque libre dans la fumée de différentes cigarettes et de deux petits cigares, on a utilisé une électrode d'ammoniaque. Afin de comparer, on a également calculé la quantité théorique d'ammoniaque libre à partir de la teneur totale en ammoniaque et du $\mathrm{pH}$ de la fumée. L'ammoniaque libre, dans des cigarettes commerciales américaines avec ou sans filtre, est présent à raison de 1 à $4 \mathrm{ng}$, pour une teneur totale en ammoniaque de 28 à $44 \mu \mathrm{g}$. La fumée d'une cigarette de tabac noir et celle d'un petit cigare contenaient respectivement 1,2 et 2,4 $\mu \mathrm{g}$ d'ammoniaque libre, pour une teneur totale en ammoniaque de 147 et $310 \mu \mathrm{g}$. La teneur calculée en ammoniaque libre concorde bien avec les valeurs expérimentales. Aucune erreur significative n'a été introduite par la méthylamine dans la fumée, ni pour l'ammoniaque libre, ni pour l'ammoniaque totale.

\section{REFERENCES}

1. Ayers, C. W.: Talanta 16 (1969) 1085.

2. Brunnemann, Klaus D., and Dietrich Hoffmann: J. Chromatogr. Sci. 13 (1975) 159.

3. Balleter, W. T., C. J. Bushman, and P. W. TidwelI: Anal. Chem. 33 (196x) 592.

4. Collins, P. F., W. W. Lawrence, and J. T. Williams: Beitr. Tabakforsch. 6 (1972) 167.

5. Sloan, C. H., and G. P. Morie: Anal. Chim. Acta 69 (1974) 243.

6. Russell, J. A.: J. Biol. Chem. 156 (1944) 457.

7. Newsome, J. R., and C. H. Keith: Tob. Sci. IX (1965) 65.

8. Jolly, William L.: The inorganic demistry of nitrogen; W. A. Benjamin, Inc., New York, $x 964$.

9. Sensabaugh, A. J., Jr., and R. H. Cundiff: Tob. Sci. 11 (1967) 25.

The authors' address:

Research Laboratories, Tennessee Eastman Company, Kingsport, Tennessee, 37662, U.S.A. 